\section{東北地方太平洋沖地震による超 高層建物の振動特性の変動}

CHANGE IN DYNAMIC CHARACTERISTICS OF SUPER HIGHRISE BUILDINGS DUE TO THE 2011 GREAT EAST JAPAN EARTHQUAKE

$\begin{array}{ll}\text { 鹿嶋俊英—事 } * 1 & \text { 小山 信— } \\ \text { 小豆畑達哉— } * 3\end{array}$

キーワード :

東北地方太平洋沖地震, 超高層建物, 強震観測, 固有周期, 減衰定数

Keywords:

The 2011 Great East Japan Earthquake, Super high-rise building, Strong motion observation, Natural period, Damping ratio

\section{Toshihide KASHIMA — $* 1$ Tatsuya AZUHATA — $* 3$}

Change in dynamic characteristics of ten super high-rise buildings during the 2011 Great East Japan Earthquake was investigated through the analyses of strong motion data.

The natural periods of two RC buildings obviously increased during the earthquake, and were not recovered after the shaking. On the other hand, change of the natural periods of eight steel buildings was extremely small.

Amplitude dependency of the natural periods of the two buildings was examined. The dependency of the natural periods to the response amplitudes was clearly recognized and the trends were different between before and after the Great East Japan earthquake.
1.はじめに

平成23年(2011年)東北地方太平洋沖地震(以下東北地方太平洋沖地 震と称す)では，東北地方から関東地方に立地するほとんどの建物は 過去に経験のない強い摇れを経験した。強震計が設置されている建 物では貴重な強震記録が採取されており，例えば何らかの損傷を受 けた建物では，明瞭な振動特性の変動が確認されている例えば1),2)。

また，首都圈の超高層建物でも多くの強震記録が得られており， その分析結果が報告されている ${ }^{3 \wedge 15)}$ 。これらの報告では，多くの鉄筋 コンクリート $(\mathrm{RC})$ 系の建物で東北地方太平洋沖地震による固有周期 の延び(固有振動数の低下)が観察されていること, 鉄骨 $(\mathrm{S})$ 系の建物 でも固有周期の延びは見られるがその程度は相対的に小さい傾向に あること，本震の強震記録や本震前後の強震記録を用いて分析する

表 1 解析対象建物

\begin{tabular}{|c|c|c|c|c|c|c|c|c|c|c|}
\hline \multirow{2}{*}{ 記号 } & \multirow{2}{*}{ 所在地 } & \multirow{2}{*}{ 構造 } & \multirow{2}{*}{ 階数 } & \multirow{2}{*}{ 竣工年 } & \multirow{2}{*}{$\begin{array}{l}\text { 頂部/ } \\
\text { 基部 }\end{array}$} & \multirow{2}{*}{$\begin{array}{l}\text { 計測 } \\
\text { 震度 }\end{array}$} & \multicolumn{2}{|c|}{$A_{\mathrm{B}}\left(\mathrm{cm} / \mathrm{s}^{2}\right)$} & \multicolumn{2}{|c|}{$A_{\mathrm{T}}\left(\mathrm{cm} / \mathrm{s}^{2}\right)$} \\
\hline & & & & & & & $\mathrm{L}$ & $\mathrm{T}$ & $\mathrm{L}$ & $\mathrm{T}$ \\
\hline $\mathrm{A}$ & 江東区 & $\mathrm{RC}$ & $32 \mathrm{~F}+\mathrm{B} 1 \mathrm{~F}$ & 1995 & $32 \mathrm{~F} / \mathrm{B} 1 \mathrm{~F}$ & 4.4 & 69 & 63 & 283 & 249 \\
\hline $\mathrm{B}$ & 中央区 & $\mathrm{RC}$ & $37 \mathrm{~F}+\mathrm{B} 1 \mathrm{~F}$ & 1988 & $37 \mathrm{~F} / 01 \mathrm{~F}$ & 4.4 & 87 & 98 & 162 & 198 \\
\hline $\mathrm{C}$ & 墨田区 & S & 19F+B2F & 1990 & $20 \mathrm{~F} / \mathrm{B} 1 \mathrm{~F}$ & 4.3 & 66 & 69 & 290 & 385 \\
\hline $\mathrm{D}$ & 千代田区 & $\mathrm{S}$ & $20 \mathrm{~F}+\mathrm{B} 3 \mathrm{~F}$ & 1994 & $20 \mathrm{~F} / 01 \mathrm{~F}$ & 4.4 & 91 & 85 & 210 & 150 \\
\hline $\mathrm{E}$ & 千代田区 & S & $20 \mathrm{~F}+\mathrm{B} 3 \mathrm{~F}$ & 1994 & $19 \mathrm{~F} / 01 \mathrm{~F}$ & 4.4 & 91 & 85 & 173 & 177 \\
\hline $\mathrm{F}$ & 千代田区 & S+ & $21 \mathrm{~F}+\mathrm{B} 4 \mathrm{~F}$ & 2000 & $21 \mathrm{~F} / \mathrm{B} 4 \mathrm{~F}$ & 4.2 & 75 & 71 & 121 & 131 \\
\hline $\mathrm{G}$ & 横浜市 & S & $23 \mathrm{~F}+\mathrm{B} 3 \mathrm{~F}$ & 1996 & $23 \mathrm{~F} / \mathrm{B} 2 \mathrm{~F}$ & 4.2 & 60 & - & 162 & - \\
\hline $\mathrm{H}$ & さいたま市 & S+ & $26 \mathrm{~F}+\mathrm{B} 3 \mathrm{~F}$ & 2000 & 27F/B3F & 4.4 & 74 & 63 & 265 & 686 \\
\hline $\mathrm{I}$ & 千代田区 & $\mathrm{S}+$ & $32 \mathrm{~F}+\mathrm{B} 2 \mathrm{~F}$ & 2007 & $32 \mathrm{~F} / \mathrm{B} 2 \mathrm{~F}$ & 4.2 & 52 & 67 & 179 & 191 \\
\hline $\mathrm{J}$ & 中央区 & $\mathrm{S}+$ & $33 \mathrm{~F}+\mathrm{B} 4 \mathrm{~F}$ & 2001 & 33F/B4F & 4.1 & 53 & 50 & 163 & 146 \\
\hline
\end{tabular}

構造の $\mathrm{RC}$ は鉄筋コンクリート造, $\mathrm{S}$ は鉄骨造, $\mathrm{S}+$ は鉄骨造制振装置付 $A_{\mathrm{B}}$ : 基部最大加速度, $A_{\mathrm{T}}$ : 頂部最大加速度
と固有周期の応答振幅に対する依存性が明瞭に表れることが指摘さ れている。都市域での長周期地震動が懸念される現在, さらに長周 期建物の実挙動に関する知見を蓄積することは，重要な課題である。

このような背景から, 本論では, 建築研究所の強震観測網などで 得られた強震記録 ${ }^{16)}$ を用い, 東北地方太平洋沖地震による超高層建物 の振動特性の変動を検討する。

\section{2. 解析対象建物}

解析の対象とした建物を, 表1に示す。首都圈に位置する20階から 37 階建ての超高層建物で, 建築研究所の強震観測網に加え, 国土交 通省建築基準整備促進事業 ${ }^{17)}$ によって強震計を設置した超高層建物3 棟を含んでいる。構造欄のRCは鉄筋コンクリート造, Sは鉄骨造を 表し，S+は制振機構を有している鉄骨 造の建物である。頂部/基部欄は，最上 階と最下階の加速度計の位置を示す。 計測震度は，東北地方太平洋沖地震時 に建物の基部で得られた加速度記録か ら算出したもので, すべての地点で震 度4であった。 $A_{\mathrm{B}}$ と $A_{\mathrm{T}}$ は，建物基部及び 頂部で得られた最大加速度であり, L は長辺方向，Tは短辺方向を表す。なお 建物 $\mathrm{G}$ はT方向の記録に異常が認めら れるため, L方向のみ対象とする。また, 建物 DとEは低層部を共通とするツイ ンタワーであり，ここでは個別に扱う。

\footnotetext{
本稿は文献 15) に追加検討を加えたものである。 独建築研究所主任研究員・博士 (工学) （干 305-0802 茨城県つくば市立原 1) (独建築研究所上席研究員・博士 (工学) 独建築研究所上席研究員 ·博士 (学術) 国土技術政策総合研究所 室長
}

Senior Research Engineer, Building Research Institute, Dr. Eng.

2 Chief Research Engineer, Building Research Institute, Dr. Eng.

*3 Chief Research Engineer, Building Research Institute, Ph.D.

Head, National Institute for Land and Infrastructure Management 


\section{3. 解析手法}

解析では，表 1 に示した基部と頂部の 2 所の加速度記録を入出力 として取り扱う。各建物において，東北地方太平洋沖地震の際に得 られた強震記録の, 初期部, 主要部, および終了部を取り上げ，そ れぞれの部分の建物の 1 次固有周期(以下固有周期 $T$ ) と減衰定数 $(h)$ を 同定し，その変動を検討する ${ }^{18)}$ 。図1に示すように，初期部(添え字I) は建物頂部の応答加速度が最初に $10 \mathrm{~cm} / \mathrm{s}^{2}$ を回って以降の 40 秒間, 主要部(添え字M)は建物の応答加速度が最大となる時刻を中心とす る40秒間, 終了部(添え字C)は応答加速度が $10 \mathrm{~cm} / \mathrm{s}^{2}$ を最後に上回った 時刻以前の 40 秒間を採っている。固有周期と減衰定数の推定は，1自 由度の線形振動系を仮定し，その応答加速度が建物頂部の観測記録 に最も適合する固有周期と減衰定数をグリッドサーチ法によって探 索する手法 ${ }^{19)}$ で行う。

\section{4. 解析対象建物の振動特性}

まず，東北地方太平洋沖地震前の各建物の振動特性の傾向を把握 する。各建物の固有周期と建物高さ $(H)$ の関係を図 2 に, 固有周期と 減衰定数の関係を図3に示寸。固有周期と減衰定数は地震動の初期部

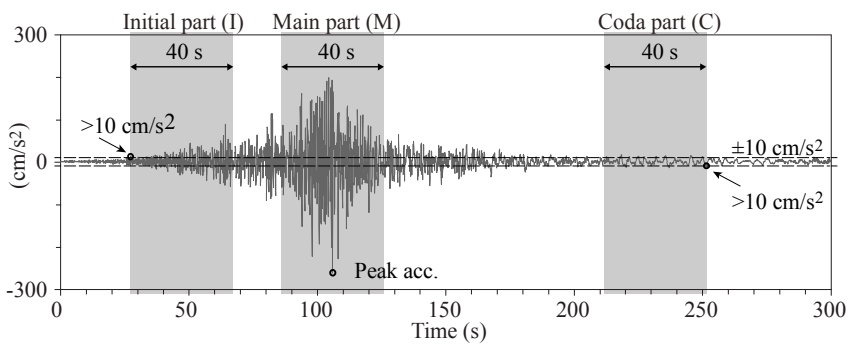

図1＼cjkstart強震記録の初期部(I), 主要部(M), 終了部(C)の定義

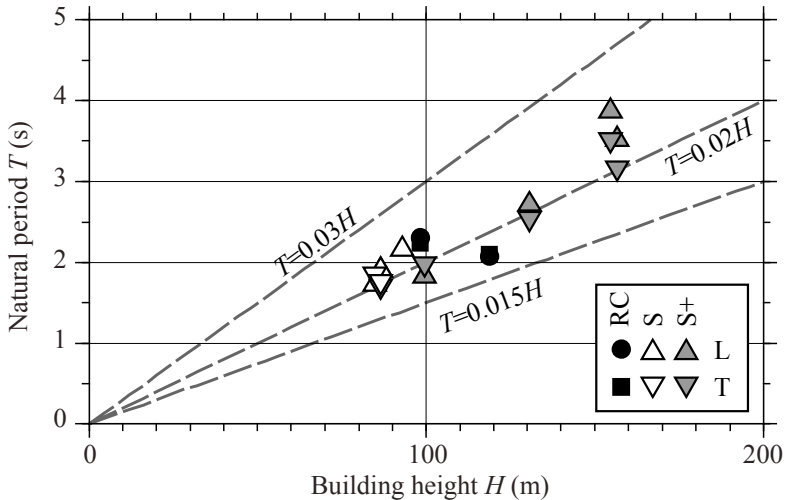

図2建物高さと固有周期 $\left(T_{\mathrm{I}}\right)$ の関係

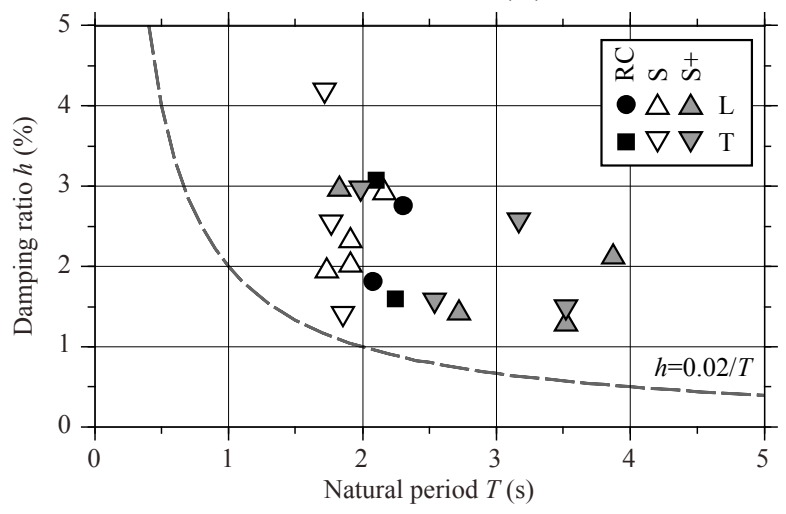

図3 固有周期 $\left(T_{\mathrm{I}}\right)$ と減衰定数 $\left(h_{\mathrm{I}}\right)$ の関係

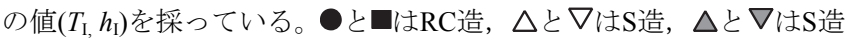

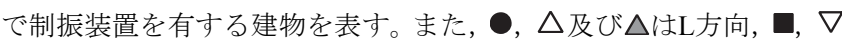
及び $\nabla$ は方向に対応する。図2を見ると，建物が高くなると固有周 期が長くなる傾向が明白に認められる。図中には，固有周期と建物 高さの関係式 $(T=0.015 H, T=0.02 H, T=0.03 H)$ を破線で示す。 $T=0.015 H$ 及び $T=0.02 H$ は微小振幅時の実測データから得られた関係式で, それ ぞれ $\mathrm{RC}$ 造及び $\mathrm{S}$ 造に対応する ${ }^{20)}$ 。また，建物の設計ではRC造で $T=0.02 H, \mathrm{~S}$ 造で $T=0.03 H$ の略算式が慣用されている ${ }^{21)}$ 。本検討で得ら れた固有周期は, $\mathrm{RC}$ 造では $T=0.02 H$ の線と調和的であり, $\mathrm{S}$ 造では概 ね $T=0.02 H$ の線の上側に分布している。

図3の固有周期と減衰定数の関係に着目寸ると，ばらつきはあるも のの, 固有周期が長くなると減衰定数が減少する傾向が表れている。 図中には，減衰定数と固有周期の関係式 $(h=0.02 / T)$ を破線で示す。筆 者らが過去に 25 棟の建物に対して中小地震の強震記録を用いて行っ た分析では, 減衰定数は $h=0.01 / T$ から $h=0.02 / T$ 間の值を示し, S造で

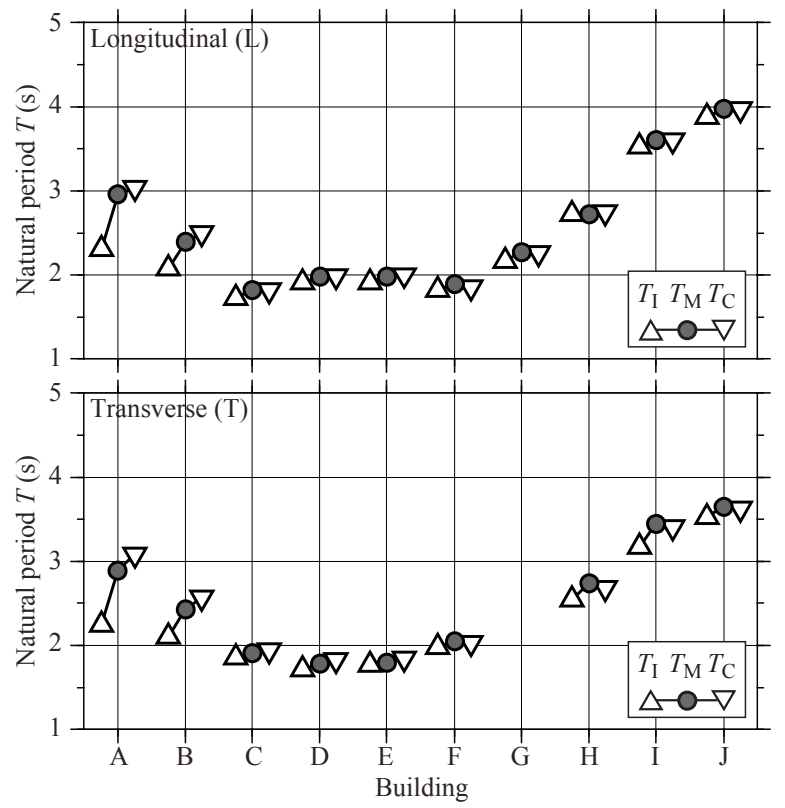

図4 東北地方太平洋沖地震時の各建物の固有周期の変化

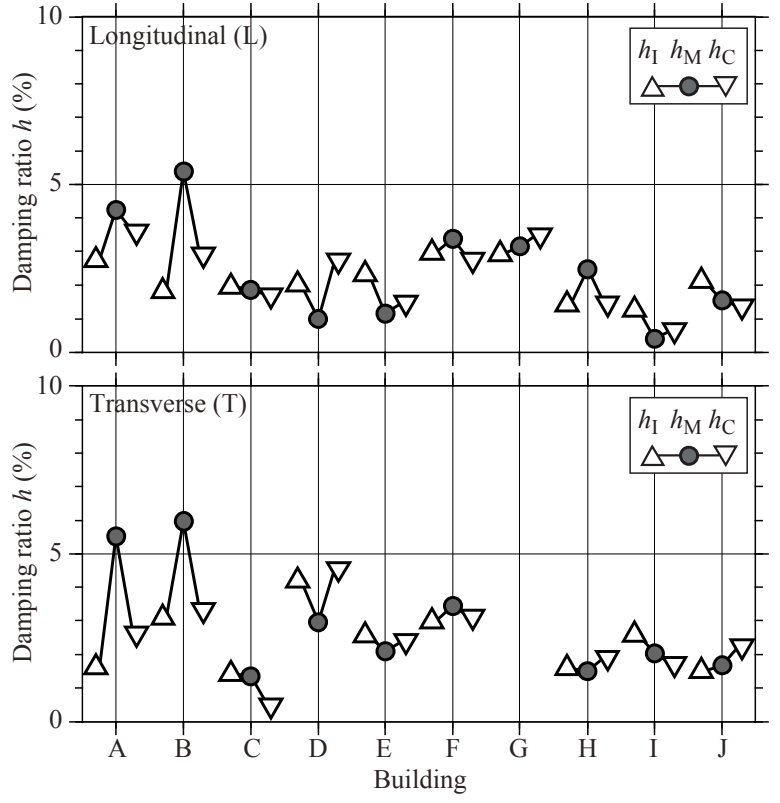

図5＼cjkstart東北地方太平洋沖地震時の各建物の減衰定数の変化 
は $h=0.02 / T$ 程度であった ${ }^{19)}$ 。ちなみに文献20)では, 微小振幅時の実測 值から, RC造で $h=0.014 / T, \mathrm{~S}$ 造で $h=0.013 / T$ という関係式を示してい る。ここで求めた減衰定数は $h=0.02 / T$ の関係式よりも大きめである。 その原因については, 構造種別や制振機構の影響, 振幅依存性など も含めさらに検討が必要である。

\section{5. 本震中の振動特性の変動}

各建物の, 初期部, 主要部及び終了部の固有周期を図4に示す。 $\triangle$ が地震動の初期部, ○が主要部, $\nabla$ が終了部の固有周期を表し, 上段 がL方向, 下段がT方向に対応する。 $\mathrm{RC}$ 造の建物 $\mathrm{A}$ と $\mathrm{B}$ で, 主要部 の固有周期は初期部に比べ30\%から $15 \%$ 程延びており, 終了部の固有 周期は初期の值に戻っていない。一方CからJのS造の建物では, 初期 部，主要部，及び終了部の固有周期にほとんど変化は見られない。

図5は, 各建物の減衰定数の地震中の変動を示している。記号は図 4 と同じである。 RC造建物(AとB)の初期部の減衰定数は $2 \%$ から $3 \%$ で, 主要部では5\%前後に増加するが, 終了部では $3 \%$ 程度に低下している。 一方, $\mathrm{S}$ 造建物(CからJ)の減衰定数はRC造よりは小さめで, 概ね $1 \%$ から3\%に分布している。初期部, 主要部, 及び終了部の減衰定数の 違いは小さい。

\section{6. 振動特性の経時変化}

さらに詳細な検討を行うために, 表1の建物のうち, 長期にわたつ て安定して強震記録が得られている建物 $\mathrm{B}$ と建物 $\mathrm{F}$ 取り上げる。建

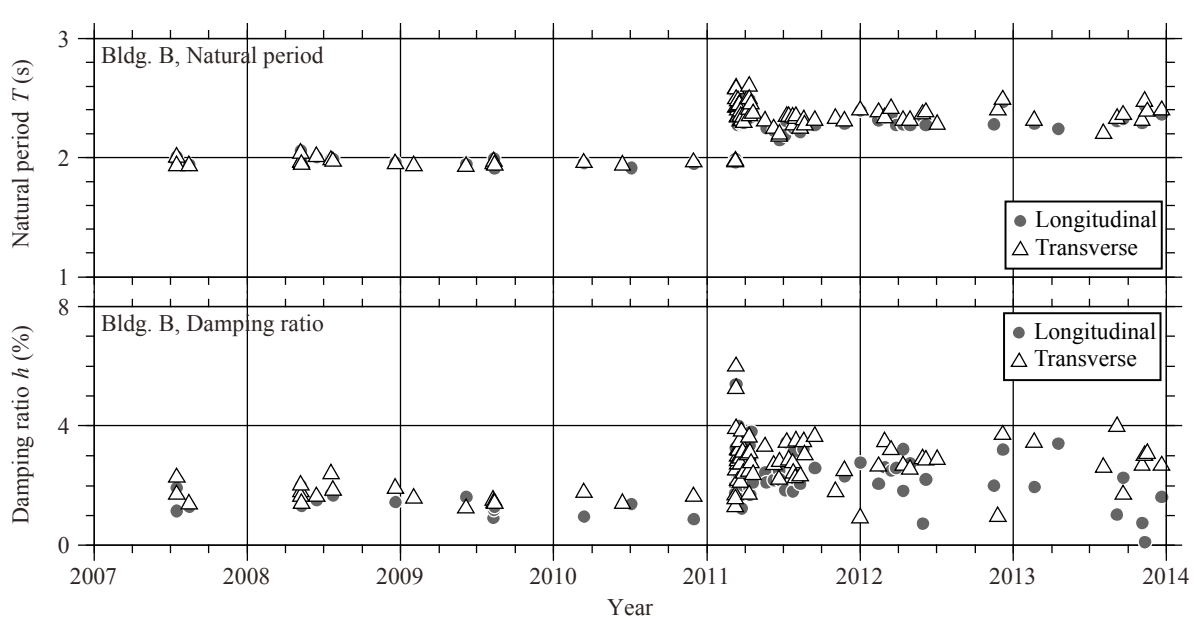

図6 建物 $\mathrm{B}$ の固有周期 $(T$, 上段) と減衰定数 $(h$, 下段)の経時変化

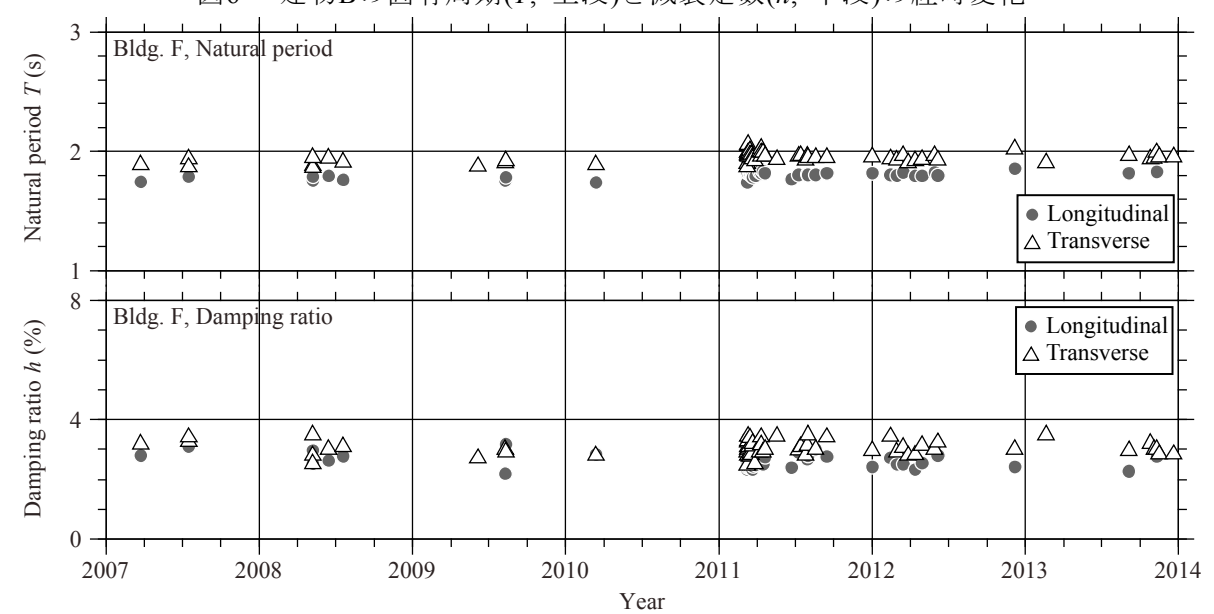

図7 建物 $\mathrm{F}$ の固有周期 $(T$, 上段) と減衰定数 $(h$, 下段) の経時変化
物 $\mathrm{B}$ はRC造37階建ての共同住宅で，建物 $\mathrm{F}$ は粘性体制振壁と極軟鋼制 振壁を有するS造21階建ての事務所建物である。

図6は, 2007年から2013年までの間の建物Bの固有周期(上段)と減衰 定数(下段)の経時変化を示している。ははL方向， $\triangle$ はT方向の值を表 す。この間に得られた強震記録のうち, 建物変位(建物頂部の基部に 対する相対変位 $)$ の最大值 $\left(\delta_{\text {max }}\right)$ が $0.2 \mathrm{~cm}$ を超えるものを取り上げ，各 強震記録から主要部の固有周期と減衰定数 $\left(T_{\mathrm{M}}\right.$ と $\left.h_{\mathrm{M}}\right)$ を前述の方法で 同定している。変位は, 高速フーリエ変換(FFT)を用いて加速度記録 を振動数領域で積分して求めている。この時, カットオフ振動数 0.2 $\mathrm{Hz}$ のローカットフィルターを用いている。

東北地方太平洋沖地震が発生するまでの固有周期は, 両水平方向 とも2秒弱で安定しており, 地震後しばらくの間2.3秒から2.6秒の值 を示している。その後は落ち着き，2.2秒から 2.4 秒の間を推移してい る。減衰定数は, 東北地方太平洋沖地震の前は $1 \%$ から $2 \%$ の低い值を 示していたが，地震を境に $1 \%$ から $4 \%$ の值を示すようになり，ばらつ きも大きい。

建物Fの振動特性の経時変化を図7に示す。記号は図6と同様である。 東北地方太平洋沖地震前の固有周期はL方向が約 1.8 秒, T方向が約 1.9 秒で，地震後も大きな差がないように見られる。減衰定数も全体的 に3\%前後の值を示しており，地震の影響は判断できない。

\section{7. 振動特性の振幅依存性}

実測された建物の固有周期は, その応答振幅に依存して変化する

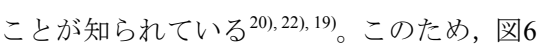
や図7に現れる同定值のばらつきには，観測 記録自体の質や同定手法に起因する誤差に 加え, 振動特性の振幅依存性に起因寸る差 異も含まれていると考えられる。ここでは, 前章と同様に建物 $\mathrm{B}$ と建物 $\mathrm{F}$ 対象として, 振動特性の応答振幅に対する依存性を考察 する。図8は，建物Bの固有周期及び減衰定 数と最大建物変位角 $\left(\theta_{\max }=\delta_{\max } / H_{\mathrm{S}}\right)$ の関係を 表す。 $H_{\mathrm{S}}$ は, 1 階床から頂部加速度計が設置 してある階の床までの高さである。上段が 固有周期, 下段が減衰定数を表し，それぞ れ左図がL方向，右図がT方向に対応する。 さらに各図の中では東北地方太平洋沖地震 の前後で記号を変えており, と山は地震前, ○と $\triangle$ は地震後の值である。固有周期に着目 すると, いずれの方向でも, 地震前と地震 後それぞれで明瞭な振幅依存性が認められ， 地震後は振幅の増加に伴う周期の延びが大 きくなっている(依存性が高まっている)よ うに見受けられる。図中には，固有周期の 最大建物变位角の常用対数に関する回帰直 線を示している。なお, 東北地方太平洋沖 地震本震の值は，回帰式の算出には用いて いない。地震前は回帰式に対する一致度も 良い(L方向相関係数 $R=0.904, \mathrm{~T}$ 方向 $R=0.931)$ が，地震後は推定した固有周期の変動が大 
きくなっている(L方向 $R=0.818, \mathrm{~T}$ 方向 $R=0.762)$ 。減衰定数を見ると, 東北地方太平洋沖地震前は相対的にばらつきも少なく, 振幅が増加 すると減衰定数が増加する振幅依存性が見られる。一方地震後は, 平均的に見ると減衰定数が増加し, ばらつきも大きくなっている。

図9は同様に，建物Fの固有周期及び減衰定数と最大建物変位角の 関係を表したものである。やはり固有周期の振幅依存性は明瞭で, その程度は東北地方太平洋沖地震の前後で大差ない。また振幅依存 性を考慮すると, 東北地方太平洋沖地震後は地震前に比べて固有周 期が0.1秒ほど延びていることが明らかとなる。減衰定数については，

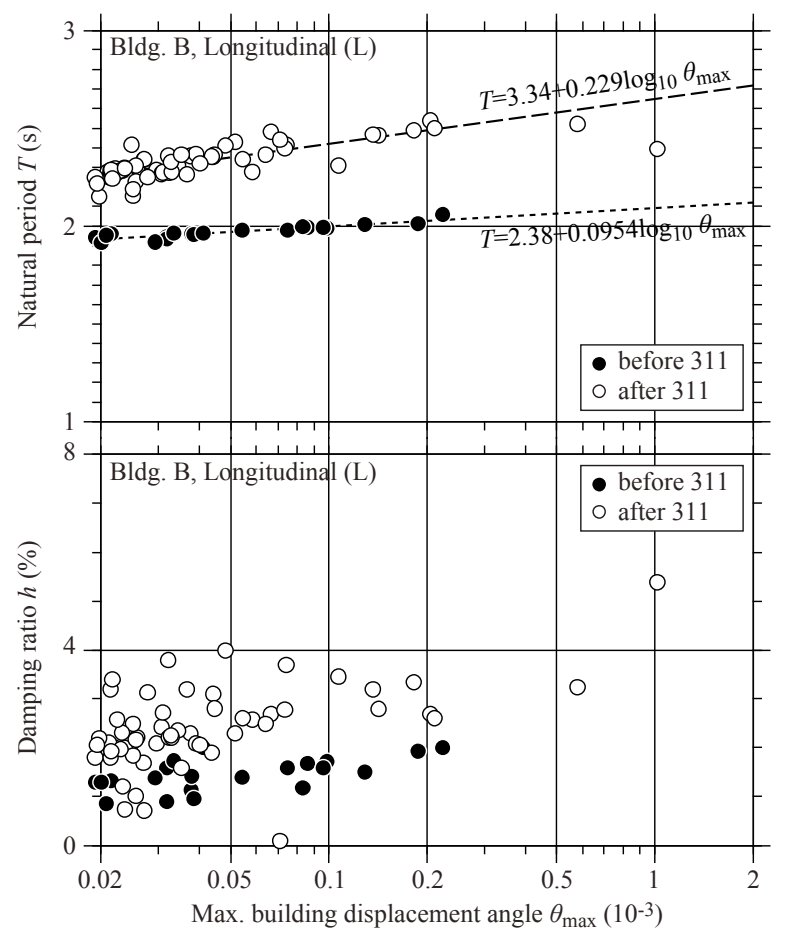

明瞭な傾向や地震前後の差異は見出し難く, 平均的に $2 \%$ から $3 \%$ の值 となっている。また, 建物Bに比べて推定された減衰定数のばらつき は小さい。

\section{8. まとめ}

首都圈に建つ超高層建物について，東北地方太平洋沖地震の際の 地震時の振動特性の変動を，強震記録を用いて検討した。2棟のRC 造の超高層建物では, 強い摇れを伴う地震の主要部で, 初期部に比 べて $15 \% か ら 30 \%$ の固有周期の延びが観察され，地震終了時にも初期

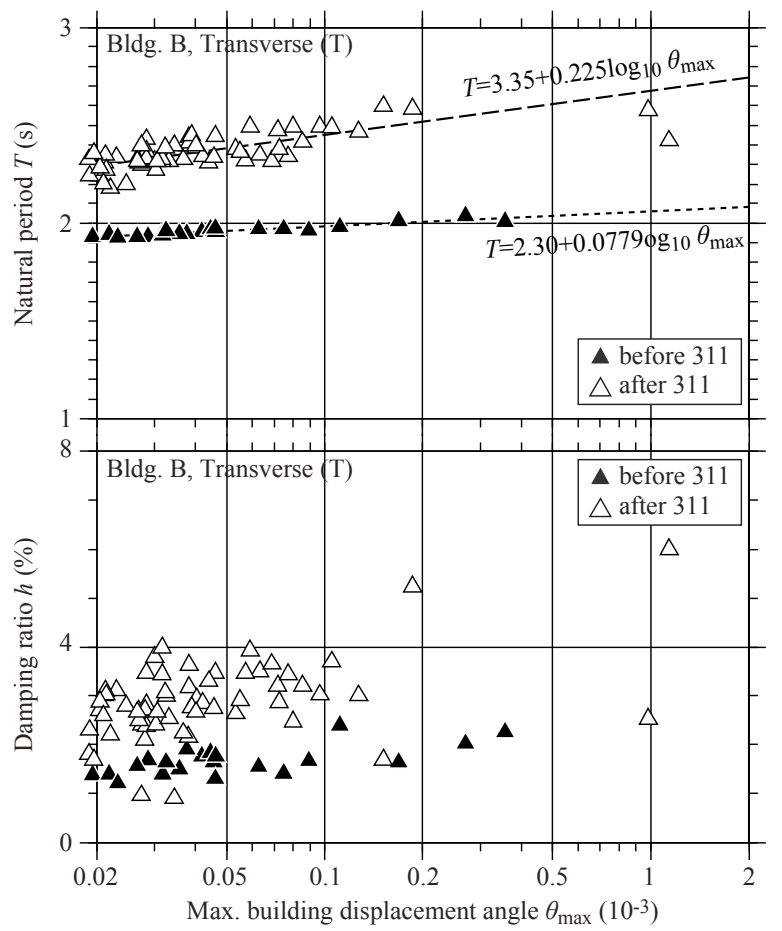

図8 建物 $\mathrm{B}$ の固有周期 $(T)$ 及び減衰定数 $(h)$ と最大建物変位角 $\left(\theta_{\max }\right)$ の関係
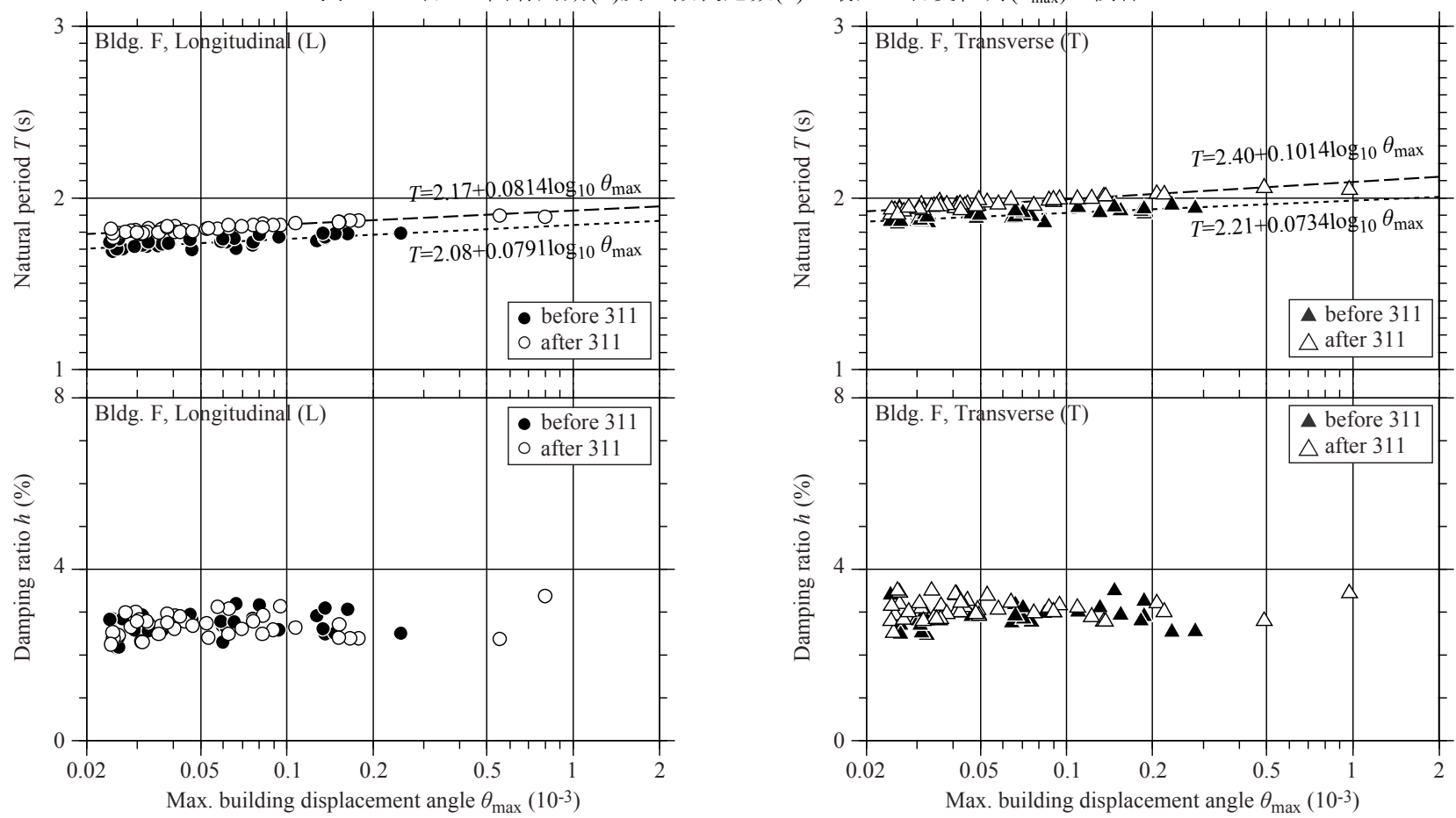

図9 建物 $\mathrm{F}$ の固有周期 $(T)$ 及び減衰定数 $(h)$ と最大建物変位角 $\left(\theta_{\max }\right)$ の関係 
の值に回復していない。首都圈の $\mathrm{RC}$ 造超高層建物の東北地方太平洋 沖地震に対する解析事例では, 応答はひび割れ点を超えているとの 報告が複数あり ${ }^{9)}$,23), 24), 当該建物でも構造体のひび割れが固有周期の 延びの原因の一つとして想定される。一方，S造の超高層建物では， 地震動の初期部, 主要部, 及び終了部の固有周期に大きな差はなか った。

減衰定数については, RC造の超高層建物では主要部で増加し, 終 了部で減少する現象が認められた。 $\mathrm{S}$ 造の超高層建物の減衰定数は $1 \%$ から $3 \%$ の值を示し, 地震動の初期部, 主要部, 及び終了部で大 きな差はなく, 明瞭な変動の傾向は認められなかった。

さらに詳細な分析を行うために，建物 $\mathrm{B}$ と建物 $\mathrm{F}$ 取り上げ，固有 周期と減衰定数の経時変化と振幅依存性を検討した。 $\mathrm{RC}$ 造の建物 $\mathrm{B}$ の場合, 東北地方太平洋沖地震の前後で明瞭な固有周期と減衰定数 の変化が確認できた。また, 地震の前後いずれにも固有周期の振幅 依存性が認められ, 依存の程度は地震後の方が高くなっていた。建 物 $\mathrm{A}$ についても同様の傾向が指摘されており ${ }^{12)}$, また別のRC超高層 建物でも類似の現象が報告されている5 ではなく, その原因についてさらなる検討が必要である。

制振機構付 $\mathrm{S}$ 造の建物Fの場合は，振幅依存性を考慮して分析する と, 東北地方太平洋沖地震の固有周期は地震前に比べて $5 \%$ 程度延び ていることが確認できた。非構造部材の緩みや制振部材の特性変化 などがその原因として考えられる。この程度の固有周期の変化は, 振幅依存性を考慮しないと見逃す可能性があり，注意が必要である。

\section{謝辞}

強震観測の実施に当たっては，各建物の管理者や利用者のご理解 とご協力を頂いている。ここに記して深く感謝の意を表す。

\section{参考文献}

1) 源栄正人, 他: 2011 年東北地方太平洋沖地震における被害建物の地震前後 の振動特性の変化, 日本建築学会大会学術講演梗概集, B-2, pp.45-46, 2011.8

2) 鹿嶋俊英: 2011年東北地方太平洋沖地震の建築研究所建物の強震記録，日 本建築学会大会学術講演梗概集, B-2, pp.319-320, 2011.8

3) 荒川洋輔, 他: 2011年東北地方太平洋沖地震にお括超高層建築の強震観 測と地震応答解析 その 1 その 3 , 日本建築学会大会学術講演梗概集, B-2, pp.305-310, 2011.8

4) 年縄巧, 他: 明星大学理工学部高層棟の強震応答特性, 日本建築学会大会 学術講演梗概集, B-2, pp. 329-330, 2011.8

5) 森下真行, 他：長期間の地震観測記録に基づく $\mathrm{R} \mathrm{C}$ 造超高層建物の動特性 評価, 日本建築学会大会学術講演梗概集, B-2, pp.695-696, 2012.9

6) 年縄巧: 2011 年東北地方太平洋沖地震前後の明星大学 27 号館の固有周期 の変化, 日本建築学会大会学術講演梗概集, B-2, pp.1137-1138, 2012.9

7) 山下哲郎, 他: 新宿区超高層街区に建つ鉄骨造超高層建築の東北地方太平 洋沖地震前後の振動特性, 日本地震工学会論文集, Vol. 12, No. 4, pp.14-26, 2012.9

8) 永野正行, 他: 2011年東北地方太平洋沖地震時の強震記録に基づく関東 • 関西地域に建つ超高層集合住宅の動特性，日本地震工学会論文集, Vol. 12, No. 4, pp.65-79, 2012.9

9) 中村尚弘, 他: 2011年東北地方太平洋沖地震における超高層SRC建物の地 震応答解析, 日本建築学会技術報告集, 第19巻, 第41号, pp.53-58, 2013.2

10) 伊藤真二, 他: 2011 年東北地方太平洋沖地震の観測データによる減衰特 性の検証, 日本建築学会大会学術講演梗概集, B-2, pp.583-584, 2013.8

11）金子知宣, 他: 微動観測に基づく超高層鉄筋コンクリート建物の強震時に おける動特性変化量推定の可能性 その1 その2, 日本建築学会大会学術
講演梗概集, B-2, pp.587-590, 2013.8

12) 中村充, 他: 超高層SRC建物の地震観測結果に見られる動特性の振幅依存 性, 日本建築学会大会学術講演梗概集, B-2,pp591-592, 2013.8

13）平山義治, 他: $\mathrm{S}$ 造19 階建てオフィスビルの観測に基づく常時微動、台風、 地震時の固有振動数の変化, 日本建築学会大会学術講演梗概集, B-2, pp599-600, 2013.8

14）森下真行, 他: RC造超高層建物の長期地震観測結果に基づく動特性評価, 日本建築学会技術報告集, 第19巻, 第45号, 527-532, 2014.6

15) 鹿嶋俊英, 他: 2011年東北地方太平洋沖地震による超高層建物の振動特性 の変動, 日本建築学会大会学術講演梗概集, B-2,pp.969-970, 2014.9

16) 鹿嶋俊英, 他: 平成23年(2011年)東北地方太平洋沖地震における建物の強 震観測記録, 建築研究資料No.135, 独立行政法人建築研究所, 2012.3

17) 国土交通省: 建築基準整備促進事業について, http://www.mlit.go.jp/jutakukentiku/house/jutakukentiku house fr 000016.html, 2014.6.16参照

18) 鹿嶋俊英, 他: 2011 年東北地方太平洋沖地震によるコンクリート系建物 の振動特性の変動, 日本地震工学会大会-2012梗概集, pp, 28-29, 2012.11

19) 鹿嶋俊英, 他: 強震観測記録から推定した建物の振動特性の特徵, 日本建 築学会技術報告集, No.22, pp.163-166, 2005.12

20) 日本建築学会: 建築物の減衰, 日本建築学会, 2000.10

21) 建設省告示第1793号, 1980.11

22）中村充: SRC造建物地震観測に基づく小振幅時動特性の振幅依存性評価, 建築学会大会学術講演梗概集, B-2,pp.949-950, 2003.9

23) 井川望, 他: 2011年東北地方太平洋沖地震における超高層集合住宅の地震 応答評価, 日本建築学会技術報告集, No.40, pp.859-864, 2012.10

24）山本健史, 他: 軟弱地盤に建つ超高層RC造集合住宅の地震応答評価と被 害との対応，日本建築学会技術報告集, No.42,pp.447-452, 2013.6

[2014 年 6 月 16 日原稿受理 2014 年 10 月 1 日採用決定 $]$ 